\title{
ELABORAREA PRIMERILOR SPECIFICI PENTRU IDENTIFICAREA MOLECULARĂ A FUNGILOR DIN G. Gaeumannomyces
}

\author{
Deaghileva Angela, Mitin V., Tumanova Lidia, Grăjdieru Cristina \\ Institutul de Genetică, Fiziologie şi Protecţie a Plantelor, Chişinău, Republica Moldova \\ e-mail: show2003@yandex.ru
}

Maladiile radiculare, care determină pierderea de 10-30\% a producţiei anuale de cereale, sunt cauzate de un complex de agenţi patogeni, cel mai frecvent, fiind identificaţi fungii din g. Fusarium, Rhizoctonia, Pythium şi Gaeumannomyces, care manifestând simptome asemănătoare, deseori sunt prezenţi pe acelaşi câmp sau chiar pe aceeaşi plantă. În Republica Moldova bolile radiculare ale grâului au fost studiate prin metode clasice, printre agenţii cauzali fiind identificaţi preponderent Fusarium, frecvent Gliocladium, Helminthosporium, etc. Gaeumannomyces graminis, care provoacă îngenuncherea grâului, este pe larg răspândit în Eurasia, inclusiv în ţara vecină Ucraina, iar în Republica Moldova unde condiţiile sunt favorabile pentru dezvoltarea lui nu se cunosc date despre prezența la culturile cerealiere. Astfel, acest patogen prezintă un risc semnificativ pentru agricultura naţională. Pentru a permite luarea măsurilor adecvate de control, care vor fi utilizate în beneficiul randamentului culturilor, este crucial ca aceest patogen să fie identificat corect şi la timp.

Identificarea Gaeumannomyces graminis a fost efectuată prin metodele PCR şi nested-PCR cu perechi de primeri specifici, creaţi pe baza fragmentului genei $M n L O X$, care este comun pentru speciile din genul Gaeumannomyces (GenBank). Testarea seturilor de primeri creaţi a fost efectuată pe ADN-ul extras din cultura mixtă de G. graminis şi din material vegetal infectat, care a fost furnizată de catedra Fitopatologie, Universitatea Naţională de Viaţă şi Ştiinţă a Mediului din Ucraina.

Caracteristicile primerilor sunt următoarele: $g g l$ - Forward, start/stop 239 p.b. - 258 p.b., lungimea - 20 p.b., $G C$ - 55\%; gg2 - Reverse, start/stop 1249 p.b. - 1230 p.b., lungimea - 20 p.b., GC - 60\%; gg3 - F, start/stop 362 p.b. - 381 p.b., lungimea - 20 p.b., GC - 55\%; gg4 - R, start/stop 952 p.b. - 934 p.b., lungimea - 19 p.b., GC $-58 \%$. Tm pentru toţi primeri este $60^{\circ} \mathrm{C}$.

În cazul utilizării diferitor combinaţii de primeri specifici cu ADN-ul extras din G. graminis în reacţia PCR au fost sintetizate următoarele fragmente: $g g 1-g g 2$-fragmentul cu lungima 1011 p.b.; gg3-gg4-fragmentul cu lungimea 591 p.b.; gg1-gg4-717 p.b.; gg3-gg2 - 888 p.b. Toate fragmentele obţinute în urma PCR corespund parametrilor calculaţi cu utilizarea aplicaţiei soft $B L A S T$. Pentru nested-PCR au fost alese următoarele perechi de primeri: runda I-gg1-gg2; runda II-gg3-gg4.

Parametrii PCR au inclus: predenaturarea $95^{\circ} \mathrm{C}-3^{\prime}$, urmată de 40 cicluri: denaturarea $95^{\circ}$ $C-1^{\prime}$, alinierea primerilor $65^{\circ} \mathrm{C}-1^{\prime}$, elongarea $72^{\circ} \mathrm{C}-1^{\prime}$, elongarea finală $72^{\circ} \mathrm{C}-7^{\prime}$.

Parametrii nested-PCR pe ADN extras din cultură de fungi au inclus în I rundă: predenaturarea $95^{\circ} \mathrm{C}-3^{\prime}$, urmată de 20 cicluri: denaturarea $95^{\circ} \mathrm{C}-1^{\prime}$, alinierea primerilor $65^{\circ} \mathrm{C}$ - 1', elongarea $72^{\circ} \mathrm{C}-1^{\prime}$, elongarea finală $72^{\circ} \mathrm{C}-7^{\prime}$, iar în a II-a rundă 20 cicluri: denaturarea $95^{\circ} \mathrm{C}-1^{\prime}$, alinierea primerilor $65^{\circ} \mathrm{C}-1^{\prime}$, elongarea $72^{\circ} \mathrm{C}-1^{\prime}$, elongarea finală $72^{\circ} \mathrm{C}-7^{\prime}$.

Parametrii nested-PCR pe ADN extras din material vegetal au inclus în I rundă: predenaturarea $95^{\circ} \mathrm{C}-3^{\prime}$, urmată de 30 cicluri: denaturarea $95^{\circ} \mathrm{C}-1^{\prime}$, alinierea primerilor $60^{\circ} \mathrm{C}$ - 1', elongarea $72^{\circ} \mathrm{C}-1^{\prime}$, elongarea finală $72^{\circ} \mathrm{C}-7^{\prime}$, iar în a II-a rundă 30 cicluri: denaturarea $95^{\circ} \mathrm{C}-1^{\prime}$, alinierea primerilor $60^{\circ} \mathrm{C}-1^{\prime}$, elongarea $72^{\circ} \mathrm{C}-1^{\prime}$, elongarea finală $72^{\circ} \mathrm{C}-7^{\prime}$.

Astfel, datele obţinute au demonstrat, că în rezultatul efectuării PCR şi nested-PCR primerii creaţi pot fi utilizaţi pentru identificarea moleculară a Gaeumannomyces spp. în material vegetal. Analiza BLAST a primerilor creaţi a demonstrat că parametrii lor respectă standardele internaţionale a Comitetului European de Standardizare (ISO 24276:2006(E)).

Cercetările au fost realizate în cadrul proiectului comun AŞM-ASŞIIU „Diagnosticul maladiilor rădăcinii grâului” (2017-2018). 